\title{
УДК 346.7
}

Г.Д. ДЖУМАГЕЛЬДІЕВА, д-р юрид. наук, старший науковий співробітник, зав. відділом проблем господарсько-правового забезпечення економічної безпеки держави Інститут економіко-правових досліджень НАН України, м. Київ

Н.В. СРЕМЕСВА, канд. юрид. наук, старший науковий співробітник Інститут економіко-правових досліджень НАН України, м. Київ

\section{ЕКОНОМІКО-ПРАВОВА СУТНІСТЬ I СТРУКТУРА ЕНЕРГОПРОСТОРУ}

\begin{abstract}
Ключові слова: світовий енергопростір, європейський енергопростір, складові енергопростору, правовий енергопростір, вільна компонента енергопростору.
\end{abstract}

(С Г.Д. ДЖУМАГЕЛЬДІЄВА, Н.В. ЄРЕМЕЄВА, 2017
На основі аналізу нормативно-правових актів Свропейського Союзу, зокрема Договору про заснування Енергетичного Співтовариства, досліджено економіко-правову сутність, визначено структуру енергопростору, природу взаємозв'язків між його ключовими елементами.

Вступ. Трансформація викликів і загроз економічної самостійності держави під впливом змін, що відбувалися в Україні протягом останньої чверті сторіччя (становлення самостійної держави та перехід до ринкової економіки, євроінтеграційний вибір з притаманними йому процесами децентралізації управління, зовнішня агресія, що супроводжується окупацією та анексією частини територіі), обумовлює перегляд чинної моделі правового забезпечення єдності загальних, групових, індивідуальних інтересів через формальне закріплення міри свободи, рівності та справедливості. Енергетика є однією зі сфер національної економіки, де дія кожного із названих факторів потребує якісної зміни філософії взаємодії держави та суспільства, насамперед, за допомогою права. Водночас об'єктивна різниця у темпах розвитку економічних відносин в енергетичній сфері та законодавства, що їх регулює, призвела до зниження спроможності права слугувати засобом задоволення справедливих потреб та інтересів, сприяти розвитку відносин, у яких зацікавлено суспільство, виконувати роль інструменту забезпечення функціонування інших соціальних інститутів (держави, економіки, соціуму та ін.), організованості та нормальної життєдіяльності, зняття соціальної напруженості тощо [1, с. 164]. Розв'язання теоретичних питань щодо змісту, структури та меж правового енергетичного простору сприятиме створенню підгрунтя для встановлення закономірностей і тенденцій його розвитку, виявленню факторів та передумов, що сприяють прискоренню, гальмуванню або змінюють напрями такого розвитку, визначенню системи принципів побудови правової моделі енергетичного простору, які, виконуючи роль «стиснутої пружини», сприятимуть посиленню точності та цільової спрямованості правових норм.

Метою дослідження $\epsilon$ визначення місця енергопростору в системі суспільних відносин, його структури, обгрунтування природи взаємозв'язків між його елементами. 
Результати дослідження. Енергопростір (світовий, європейський) як правове явище згадується у законодавстві України [2] в контексті основних напрямів енергетичної політики. Водночас ратифікація Угоди про асоціацію 3 EC передбачає інтеграцію України до єдиного європейського простору, що потребує визначення сутності такого простору в енергетичній сфері. Комплексний аналіз теоретичного доробку з цього питання свідчить, що узагальнювальне поняття «простір» охоплює певне середовище, підгрунтя, сприятливі обставини, необхідні для співробітництва всіх учасників відповідних процесів, а також для їхнього поглиблення та розширення. Наприклад, європейський правовий простір визначають як правове середовище, у якому діють норми права EC, міжнародного права та норми національного права, якщо вони не суперечать праву СС [3, с. 65-73].

Теорія європейського енергопростору поки ще перебуває в стадії становлення, натомість системний аналіз основоположних нормативно-правових актів $\mathrm{EC}$, зокрема Договору про заснування Енергетичного Співтовариства (далі Договір), дає змогу визначити об'єктивні форми його існування у загальному економічному, політичному, інституційному середовищі EC. Так, у Преамбулі до Договору енергопростір розглядають крізь призму таких його проявів як: інтегрований ринок природного газу та електроенергії на основі спільних інтересів і солідарності; стабільна регуляторноринкова структура, здатна залучати інвестиції в газові мережі, мережі виробництва та передачі електроенергії; єдиний простір регулювання торгівлі газом та електроенергією, що є необхідним для відповідності географічним розмірам товарних ринків, яких це стосується.

Отже, за функціональним критерієм складові, охоплені енергоринком, можна означити так: торговельно-виробнича як сукупність суспільних відносин у сфері обміну, за допомогою яких здійснюється реалізація природного газу та електроенергії та / або послуг, пов'язаних з їхнім виробництвом, переміщенням, споживанням тощо; інвестиційна - як сукупність суспільних відносин у сфері розміщення майнових та інтелектуальних цінностей в об’єкти виробництва, розподілу, транспортування, споживання природного газу та електроенергії та пов'язані з ними послуги, у результаті якої створюється прибуток (доход) або досягається соціальний ефект; регулятивна - як сукупність суспільних відносин у сфері управління сферою виробництва, обігу і споживання природного газу та електроенергії та пов'язані $з$ ними послуги.

Наведене структурування є досить умовним, адже відносини, зараховані до певного виду, перебувають у тісному взаємозв'язку. Так, прибуток, що утворюється внаслідок здійснення торгово-виробничої діяльності, може бути джерелом інвестування (самоінвестування) у техніко-технологічну модернізацію суб'єкта господарювання. У певних випадках таке «перетікання» 3 одного сегмента до іншого передбачено законодавством, тобто реалізується завдяки регулятивній компоненті. Зокрема, п. 2.4, 3.9.1 Умов та Правил здійснення підприємницької діяльності з передавання електричної енергії магістральними та міждержавними електричними мережами зобов'язують оптового постачальника електроенергії щорічно здійснювати інвестування у розвиток мережевого господарства оператору магістральних мереж [4]. Водночас значення наведеного розподілу енергопростору за функціональним критерієм створює передумови для оцінки ефективності та достатності наявного обсягу компетенції або доцільності прямої законодавчої заборони щодо можливості акторів брати участь у відповідних відносинах (торговельно-виробничих, інвестиційних, регулятивних тощо).

У відносинах, що складаються в енергопросторі, діють різні за правовим статусом та суб'єктними ознаками учасники (фізичні особи, суб'єкти господарювання, органи місцевого самоврядування, органи державної влади, територіальні громади, держава тощо). Таких учасників за критерієм інтересу, на досягнення якого спрямовані їхні дії, умовно можна згрупувати за основними рівнями - індивідуальним, колективним, національним, наднаціональним.

На індивідуальному рівні учасники виступають від власного імені та переслідують власний (індивідуальний) інтерес. У видовому розрізі зазначений рівень представлений фізичними особами, суб'єктами господарювання, органами місцевого самоврядування, органами державної влади. Так, у торговельно-виробничому сегменті фізичні особи можуть бути як споживачами енергії (побутовими спожива-

ISSN 1681-6277. Економіка та право. № 3 (48), 2017 
чами), так і її виробниками та продавцями у разі реалізації енергопостачальникам за регульованим тарифом надлишків енергії, виробленої з енергії сонячного випромінювання та / або енергії вітру об'єктами електроенергетики (генерувальними установками) приватних домогосподарств, величина встановленої потужності яких не перевищує 30 кВт, у порядку, визначеному національною комісією, що здійснює державне регулювання у сферах енергетики та комунальних послуг (ст. 15 Закону України «Про електроенергетику»). При цьому, на відміну від інших виробників енергії, у т. ч. з альтернативних джерел, фізичні особи не набувають додаткових характеристик ані як суб'єкти енергоринку (не вступають до Оптового ринку електроенергіi), ані як суб'єкти господарювання (їхня діяльність 3 виробництва електроенергії не потребує ліцензій або спеціальних дозволів).

В інвестиційному сегменті фізичні особи можуть бути як інвесторами (самоінвестування), співінвесторами, так і реципієнтами інвестицій. У першому випадку йдеться про будівництво енерогенерувальних установок для виробництва енергії з альтернативних джерел; самостійне впровадження заходів з енергозбереження та підвищення енергоефективності власних будинків за рахунок власних або залучених коштів (наприклад у рамках передбаченої державної програми «теплих кредитів»). Результатом здійснених інвестицій є зменшення витрат на енергетичні житлово-комунальні послуги, що сприяє збільшенню загального доходу домогосподарства. У другому випадку здійснення таких заходів може відбуватися за допомогою спеціалізованих енергосервісних компаній на договірних засадах у порядку, передбаченому Законом України «Про запровадження нових інвестиційних можливостей, гарантування прав та законних інтересів суб'єктів підприємницької діяльності для проведення масштабної енергомодернізації». Результатом інвестування для енергосервісних компаній є отримання прибутку упродовж усього терміну дії договору на енергосервісне обслуговування, розмір якого залежить від обсягу щорічного скорочення витрат замовника енергосервісу на оплату паливно-енергетичних ресурсів, житлово-комунальних послуг порівняно з витратами, що були б здійснені за відсутності енергосервісу (ч. 3 ст. 5 зазначеного Закону).
Також окремі категорії споживачів пільгових категорій можуть бути реципієнтами інвестування з боку держави, зокрема у разі надання їм субсидій (чи є це інвестуванням?) на сплату послуг з тепло-, електро- та газопостачання, внаслідок яких досягається соціальний ефект забезпечення належного обсягу отримання усіма громадянами житлово-комунальних послуг як елемент гарантованого Конституцією України достойного рівня життя. Умовно до опосередкованого інвестування споживача 3 цією ж метою може віднести міжбюджетні трансферти місцевим бюджетам. Але відсутність у органу місцевого самоврядування як отримувача такого трансферту жодної функції інвестиційного характеру певною мірою «розмиває» інвестиційну спрямованість зазначеного заходу.

Суб'єкти господарювання у торгово-виробничому сегменті енергопростору $є$ і споживачами енергії, і виробниками, для яких діяльність із виробництва енергії або видобування енергоресурсів $\epsilon$ основною (генерувальні, добувні підприємства) або неосновною, тобто здійснюється винятково для задоволення власних потреб у енергії (виробники метанової енергіi). В інвестиційному сегменті суб'єкти господарювання можуть здійснювати професійну інвестиційну діяльність у енергетичному секторі (банки, інвестиційні та венчурні фонди, енергосервісні компаніі), а також бути реципієнтами інвестицій з боку держави або органу місцевого самоврядування (оплата комунальних послуг бюджетних закладів, капіталізація статутного фонду державних корпорацій, дотації вугільних шахт тощо). У першому випадку мета (планований результат) кожного з учасників інвестування випливає 3 договору та забезпечується його умовами. У другому - інвестиційна мета не завжди простежується, отже про прибутковість інвестування не йдеться, а в окремих випадках спостерігається недотримання конституційного принципу рівності суб’єктів господарювання різних форм власності та несумісність із вимогами щодо справедливої конкуренції.

Органи місцевого самоврядування, окрім звичайного споживання енергії, можуть брати участь у відносинах із виробництва енергії як постачальники енергоресурсів, а саме відходів, власниками яких вони є відповідно до ст. 9 Закону України «Про відходи». В Україні по- 
тенціал зазначених органів бути активними учасниками торговельно-виробничого сегмента енергопростору не використовується через незлагодженість галузевих концепцій екологічного та господарського права. Так, еколого-правова конструкція відносин з приводу відходів у загальному вигляді передбачає комплекс дій органу місцевого самоврядування, що спрямовані на забезпечення безпечного навколишнього середовища, складовою якого є збирання та видалення відходів. (ст. 21 Закону України «Про відходи»). Найпоширенішим способом видалення $€$ вивіз відходів на сміттєзвалище, але останні події у Львівській області довели вичерпність цього підходу. Наявні еколого-правові конструкції, з огляду на галузеву мету та предмет, не враховують потенціальну можливість власника відходів на отримання прибутку від реалізації тих об'єктів права власності, які ним вже не можуть використовуватися, зокрема шляхом продажу відходів як енергетичної сировини. Едина пропозиція 3 цього приводу - укладання договору на послуги з утилізації відходів зі сміттєпереробними підприємствами, що виробляють тепло- та електроенергію або паливні брикети. Але договірна конструкція передбачає лише витрати з боку власника відходів, який є замовником відповідної послуги, що суттєво нівелює зацікавленість у такому співробітництві або в інвестуванні (співінвестуванні) у будівництво власних сміттєпереробних заводів, діяльність яких мала б енергетичне спрямування та давала змогу, окрім екологічних, вирішувати й частину енергетичних проблем населеного пункту.

У випадку, коли передання сміття на умовах договору про утилізацію відбулося, спостерігається дивна трансформація його правового режиму: ліквідоване (утилізоване) як об'єкт комунальної форми власності сміття мов «міфічний птах Фенікс» 3'являється у господарсько-правових відносинах вже у вигляді енергосировини для виробництва енергопродуктів, право власності на яку належить переробному підприємству на підставі договору на утилізацію. Вартість цієї сировини враховується для визначення тарифу на енергію (брикети), що виробляє підприємство. Однак вона не лише не була сплачена переробником, а й частково відшкодована у вигляді плати за утилізацію. Оскільки така трансформація правового режи- му відбувається поза рамками господарськоправового етапу «життєвого циклу» відходів, вона не враховується нормами господарськоправових інститутів - ціноутворенням, конкурентним правом, оподаткуванням тощо. Через неузгодженість еколого-правового і господарсько-правового підходів викривлюється економічна сутність відносин з раціонального переміщення ресурсів, що, на думку Р. Познера, не є ознакою помилковості або безгосподарності власника (власників), а скоріше свідчить про наявність перешкод вільному та економічно обгрунтованому руху ресурсів, які призводять до скупчення сукупної «вартості можливості» в одному центрі, замість іiі справедливого розподілу за рухом ресурсу [5, c. 39].

Зазначені перешкоди консервують потенціал органів місцевого самоврядування в $i н-$ вестиційному сегменті. Попри досить розвинену систему форм участі зазначених органів у співінвестуванні в енергосектор на умовах державно-приватного партнерства, у рамках місцевих програм розвитку, спостерігаються лише поодинокі випадки такого співробітництва. Наприклад, договір концесії цілісного майнового комплексу КП «Артемівськтепломережа», укладений між міською радою та литовською компанією Energija. Можливості органів місцевого самоврядування як реципієнтів інвестицій обмежуються в результаті розбіжностей їх позиціонування у фінансовота господарсько-правовій моделі регулювання. За таких умов єдиною «гілкою», по якій можуть надходити інвестиції до цих органів, $\epsilon$ фінансово-правова - міжбюджетні трансферти або інші прямі надходження.

Участь органів державної влади проявляється у формі реалізації ними повноважень, що відповідають меті та завданням їхньої діяльності. При цьому в контексті дослідження не $є$ важливим розмежування між діями органу державної влади як носія індивідуального (службового, відомчого) та виразника публічного інтересу (як визнаного державою та забезпеченого правом інтересу соціальної спільноти, задоволення якого служить умовою і гарантією їі існування та розвитку [6, с. 203223]) з огляду на те, що у будь-якому разі орган державної влади діє від власного імені та відповідно до визначеного законом обсягу його господарської компетенції.

ISSN 1681-6277. Економіка та право. № 3 (48), 2017 
У торговельно-виробничий сегмент енергопростору органи державної влади на сучасному етапі залучені через систему дій, пов'язаних iз безпосередньою закупівлею енергоресурсів, насамперед природного газу, торгівлею квотами на викиди, які було отримано внаслідок запровадження енергоефективних технологій у реальному секторі економіки, але не реалізовано їх виробником самостійно. В інвестиційному сегменті вони зазвичай $є$ активним гравцем - засновник національних корпорацій, замовник основних робіт із геологорозвідування, будівництва трубопровідної інфраструктури тощо.

На колективному рівні уособлюється загальний інтерес певної однорідної групи індивідуальних учасників. Відповідне групування індивідуальних учасників може здійснюватися як з економічних, так і юридичних підстав. Так, законами України «Про електроенергетику», «Про ринок природного газу», «Про теплопостачання» 3 метою встановлення спільного підходу до правового регулювання в окремих сферах (нормування, ціноутворення тощо) фізичні особи об'єднані у категорію населення, яка у певних випадках може поділятися на підкатегорії (вразливе населення та ін.). Сукупність суб'єктів господарювання, які функціонують в одному секторі економіки (споріднених секторах), наприклад енергетичному, утворюють інституціоналізовані або неінституціоналізовані галузеві об'єднання (галузь економіки, асоціація вітроенергетики, Оптовий ринок електроенергії тощо), спільність інтересу яких може бути відображена у державних та регіональних програмах та стратегіях галузевого розвитку (Енергетична стратегія України, Державна цільова економічна програма енергоефективності та ін.), нормативно-правових актах (Закон України «Про альтернативні джерела енергії»), організаційних договорах (Договір між членами Оптового ринку електроенергії України).

Торговельно-виробничий сегмент є основною сферою діяльності відповідних учасників. Колективний характер дій має класичний прояв на енергоринку - у обов'язковій координації всіх характеристик виробничих процесів оператором ринку. Але наявне сьогодні виведення 3 колективного кола першого етапу - постачання енергоресурсів виробникам - скорочує можливість оперативного маневрування та ISSN 1681-6277. Економіка та право. № 3 (48), 2017 загрожує безпеці енергоринку. Загальна колективна мета енергоринку - забезпечення надійного функціонування - обумовлює певну колективність дій у інвестиційному сегменті. Так, відповідно до п. 3.6. Договору між членами Оптового ринку електроенергії, основним інвестором у магістральну мережеву інфраструктуру є оптовий постачальник, який закладає у розрахунок тарифів на енергоринку відповідну інвестиційну складову, що дозволяє говорити про колективну природу інвестування.

На національному рівні носієм ексклюзивного інтересу є український народ. Торговельновиробничий сегмент представлений абсолютним правовідношенням власності українського народу щодо усіх природних ресурсів, які використовуються або можуть використовуватися для виробництва енергії. Узагальнення наукових розробок із проблематики правосуб'єктності українського народу дає змогу виокремити активну та пасивну форми прояву права власності. Зокрема, активна форма реалізації зазначеного права в літературі визначена як забезпечена законодавством правомірна, вольова, охоронювана державою міра можливої діяльності власника, що проявлено у вчиненні відповідно до закону дій, спрямованих на додержання норм права в реалізації правомочностей володіння, користування, розпорядження природними ресурсами з метою задоволення потреб загальносуспільних інтересів шляхом використання власності $[7$, c. 6]. Найяскравішим прикладом активної форми реалізації права власності народом серед європейських країн $є$ Швейцарія, законодавство якої передбачає визначення юридичної долі «будь-яких об'єктів публічної майнової сфери, що використовуються в цілях публічного управління» виключно на державному, кантональному або муніципальному референдумах за умови попереднього позитивного висновку екологічної експертизи та схвалення iï висновків громадськими організаціями (ст. 1 Закону про використання територіі) [8, с. 253-260; 9, с. 28]. Зокрема, 12.02.2017 відбувся державний референдум, на якому підтримана урядова Енергетична стратегія-2050, що передбачає відмову від збільшення кількості АЕС та нарощування частки атомної енергії в енергобалансі (35\% у 2016 р.), а також державне субсидіювання переходу до альтернативної енергетики (60\% 
у енергобалансі, з них більше $90 \%$ - гідроенергетика) [10].

Пасивна форма (здійснення права власності від імені українського народу) обумовлена потребами та інтересами українського народу як суб'єкта права власності на природні ресурси в межах території України, регламентована реалізація функцій і повноважень органів державної влади та місцевого самоврядування, спрямована на забезпечення реалізації у відповідних правових формах конституційних вимог щодо права власності українського народу, його гарантування та захист відповідно до положень Основного закону [7, с. 6].

У інвестиційному сегменті енергопростору поточний стан інвестування у національні інтереси, носієм яких є український народ, відображується у категорії «розвиток людського потенціалу», яка своїм корінням виходить із аристотелевського вчення щодо оцінки соціальних заходів за критерієм міри, у якій вони рухають «людське благо», що розвинута у працях Е. Канта, У. Петті, Г. Кінга, А. Лавуазьє, Дж. Лагранжа, А. Сміта, Д. Рікардо та ін. У розумінні ПРООН - ініціатора впровадження цієї дефініції у сучасний міжнародний термінологічний обіг, людський розвиток є процесом розширення вибору людей шодо ведення довгого та здорового життя, набуття знань та отримання доступу до ресурсів, що є необхідними з огляду на стандарти достойного життя, на здійснення інших цілей, які на їхню думку, мають цінність; активна участь у забезпеченні справедливості та сталості розвитку на планеті [11, с. 10-11; 12, с. 2-4]. Інвестування у людський розвиток є ключовим завданням кожної держави, яке, як правило, декларується на конституційному рівні.

Одним зі стрижньових індикаторів визначення рівня людського розвитку є рейтинг споживання електроенергії, що, по-перше, свідчить про визначальну роль енергетики у забезпеченні національного інтересу, по-друге, обумовлює іiї основні ціннісні постулати: розвиток людей, розвиток людьми, розвиток для людей. У першому напрямі інвестування здійснюється у будівництво енергетичної інфраструктури та забезпечення безпеки з метою створення передумов для задоволення усе більшого попиту на енергію, пов'язаному в т. ч. із загальним економічним зростанням; у другому - у наукові розробки в енергетичній сфері та підтримку малих форм генерації (приєднання приватних установок до мереж); у третьому - у доступність енергії, екологічність генерації та раціональність енергоспоживання. Цілі сталого розвитку на період 2016-2030 pp., ухвалені на Саміті ООН, як магістральні напрями інвестування в енергетичній сфері, які сприятимуть людському розвитку, визнають забезпечення загального доступу до недорогого, надійного і сучасного енергопостачання, збільшення частки енергії з відновлюваних джерел у енергобалансі, підвищення енергоефективності, полегшення доступу до досліджень і технологій у цій галузі.

Правосуб'єктність народу як інвестора має прояв у його участі у суверенних фондах добробуту, активне створення яких почалося у середині 2000-х рр. Україна наразі не має досвіду формування таких фондів, але теоретичний пошук правової моделі залучення українського народу здійснювали В.К. Мамутов, Б.Г. Розовський, Ю.В. Макогон, В.І. Ляшенко, В.А. Устименко, Р.А. Джабраілов [13, с. 5-18; 14 , c. $85-94 ; 15$, с. $8-41 ; 6$, с. $114-115 ; 17$, c. 7-20] та ін. Деякі аспекти зазначеної проблематики в умовах перехідної та ринкової економіки досліджували Д.С. Львов, Р.А. Познер, Д.Д. Хаддок, Д.У. Аллен та ін. [18, с. 1819 ; 5, с. $85-86 ; 19$, с. $775-792$; 20, c. 1-23]. Узагальнення наявних теоретичних розробок та законодавства України дають змогу виділити майнову та грошову форми інвестицій, які здійснюються (можуть здійснюватися) українським народом у рамках енергопростору.

У разі майнових інвестицій мова йде про консервацію певних родовищ базових енергоресурсів (нафта, природний газ, вугілля), створення стратегічних запасів зазначених енергоресурсів, надання у встановленому законом порядку суб'єктам господарювання права на використання належних власнику природних ресурсів для цілей енергетики (надра, земля, атмосферне повітря, водні ресурси тощо). Принциповим в останньому випадку $є$ дотримання саме національного інтересу - задоволення потреб наявних поколінь з одночасним збереженням права майбутніх поколінь на використання ресурсів або сукупної вигоди від їхньої реалізації (у т. ч. виснаження), на забезпечення якого має спрямовуватися чинний правовий механізм інвестування. Неврахування права на використання ресурсів у

ISSN 1681-6277. Економіка та право. № 3 (48), 2017 
майбутньому як частини інтересу українського народу призводить до системного порушення персоніфікації отримувача вигоди, коли ним стає не власник (одноосібно або на паритетних засадах), а «зовсім стороння особа»виробник ресурсів, інтерес якого, незалежно від форми власності, є індивідуальним. Аналогічні наслідки усунення власника від належної йому винагороди спостерігаються за відтермінування реальної реалізації суб'єктом господарювання придбаного права користування родовищем викопних ресурсів, вартість яких із урахуванням вичерпності світових запасів із часом підвищується. Певним чином таку ситуацію «схвалює» законодавство. Зокрема, відповідно до Закону України «Про нафту і газ», користувач управі без поважних причин не розпочинати користування нафтогазовим родовищем протягом 180 календарних днів із моменту початку строку дії (за чинним порядком саме такий термін використовують для фіксації ціни на нафту на світовому ринку, на підставі якої визначається ціна природного газу) та два роки - щодо родовищ інших енергетичних корисних копалин [20].

Інвестування у грошовій формі здійснюється через механізми функціонування суверенних фондів, початок активного створення яких припадає на середину 2000-х pp. [22]. Міжнародний валютний фонд за критерієм мети створення таких фондів окремо виділяє ощадні фонди для майбутніх поколінь, створені 3 метою конвертації невідновлювальних сировинних активів у портфель диверсифікованих активів та формування запасу фінансової міцності на майбутнє [23, с. 35-41]. Одним із джерел надходження до таких фондів, що матимуть «енергетичне походження», можуть бути частина прибутку від експорту енергоресурсів, зокрема здійснюваного недержавними суб'єктами господарювання, плата за використання нафтогазових та вугільних родовищ, частина податку на прибуток, у т. ч. від експорту, що сплачують енергогенерувальні підприємства, які виробляють енергію з традиційних енергоресурсів тощо. Окремі суверенні фонди, зокрема у штаті Вайомінг (США), Норвегії, Польщі податкові та інші прямі надходження видобувних підприємств та доходи від інвестиції цих прибутків відокремлюють від загальних джерел фонду та акумулюють у постійному сировинному цільовому фонді [24].
Як свідчить моніторинг діяльності таких фондів, здебільшого вони беруть участь у проектах, розрахованих на довготривалу перспективу. У структурі активів фонду в середньому 3/4 представлено цінними паперами, насамперед, венчурних компаній, інших суверенних фондів і державними облігаціями інших країн [25]. 3 міркувань економічної безпеки та мети створення суверенні фонди зазвичай не інвестують всередині країни (у Норвегії, Азербайджані й Чилі встановлена законодавча заборона 3 цього приводу), або відіграють роль прямих інвесторів, розмішуючи нейтральну для компанії та курсу національної валюти суму (у межах $1 \%$ ). Але, наприклад, у Польщі встановлено обмеження діяльності фонду лише внутрішнім ринком цінних паперів $\mathrm{i}$ співпрацею винятково з державними інституціями та компаніями. У штаті Аляска діяльність Alaska Permanent Fund також має обмеження за територією та способом використання - виключно виплата щорічних дивідендів мешканцям Аляски, що наразі набуває значення негативного фактору, який провокує підвищення цін, соціальне утриманство і безробіття, тимчасові сплески попиту на товари широкого вжитку. У Новій Зеландії, Норвегії, Польщі зазначені фонди здійснюють позитивний вплив на довгострокову екологічну та соціальну політику. Так, у 2014 р. суверенний фонд Норвегії отримав дозвіл парламенту на продаж усіх вугільних енергетичних активів, що йому належали на праві власності [26, c. 56-73], що надало суттєвий поштовх переорієнтації національної енергетики на екологічніші, насамперед відновлювальні джерела енергії.

У Польщі створення суверенного фонду (Węglowodorowy Fundusz Pokoleń) пов'язане 3 перспективою освоєння покладів сланцевого газу у поєднанні з очікуваним зростанням ролі у регіональній торгівлі газом. Окрім накопичення коштів на перспективу, польський суверенний фонд бере участь у забезпеченні майбутніх поколінь шляхом використання коштів, зокрема на навчання, вищу освіту, наукові дослідження та підтримку охорони здоров'я теперішніх поколінь.

На наднаціональному рівні носієм інтересу є держава як суб'єкт міжнародних відносин, яка забезпечує виконання покладених на неї Конституцією України завдань щодо захисту 
економічного суверенітету, складовою якого $\epsilon$ енергетична безпека, забезпечення участі України у зовнішньоекономічній діяльності (ст. 17-18 Конституції України). Так, відповідно до ст. 7 Закону України «Про основи національної безпеки», основними загрозами у сфері енергетичної безпеки є неефективність використання паливно-енергетичних ресурсів, недостатні темпи диверсифікації джерел їхнього постачання та відсутність активної політики енергозбереження, що створює загрозу енергетичній безпеці держави. У зазначених сферах держава виконує торгово-виробничу, інвестиційну, регулятивну функції.

У торговельно-виробничому сегменті держава наразі бере участь у закупівлі природного газу, виступаючи в угодах, укладених ПАТ «НАК «Нафтогаз України», як виконавець фінансових зобов'язань за основним договором, зокрема $з$ оплати імпортованого від європейських постачальників природного газу, або виконавець зобов'язань за допоміжними договорами, зокрема боргових зобов'язань за кредитами, залученими від міжнародних фінансових організацій та фінансових установ для закупівлі імпортованого газу європейських, а також відшкодування витрат міжнародних фінансових організацій за гарантіями за такими кредитами (ч. 2 ст. 6 Закону України «Про Державний бюджет України на 2017 рік»). Треба зауважити, що такий формат відносин не відповідає засадничим позиціям законодавства $\mathrm{CC}$, наприклад щодо конкуренції та державної підтримки. Досить вразливим він $є$ і у контексті національного права, стосовно загальних положень правової доктрини щодо юридичної особи, господарської компетенції, теорії договору.

В інвестиційному сегменті держава виконує функції інвестора (наприклад під час виділення коштів на фінансування «теплих» кредитів) або бере участь у забезпеченні виконання зобов'язань шляхом надання гарантії за кредитами (позиками) суб'єктів господарювання, що залучаються для фінансування інвестиційних проектів, у вугільній галузі з метою модернізації та технічного переоснащення шахт (ч. 1 ст. 6 Закону України «Про Державний бюджет України на 2017 рік»).

Сутність дій Енергетичного Співтовариства зі створення європейського енергетичного простору у ст. 2 Договору визначена як орга- нізація зв'язків між Сторонами й створення правової та економічної бази стосовно енергопродуктів і матеріалів, для транспортування яких використовують мережі (природний газ, теплова та електрична енергія) (далі мережеві енергопродукти). Отже, у загальному вигляді європейський енергетичний простір можна визначити як систему зв'язків між сторонами (і відповідно на національному рівні - внутрішніми «гравцями» - суб'єктами організаційно-господарських повноважень, суб'єктами господарювання та споживачами) 3 приводу обігу мережевих енергопродуктів, структура якої охоплює юридичний та інші (економічний, технічний тощо) елементи. На користь такого висновку свідчить аналіз ст. 3 Договору, яка містить вичерпний перелік ключових завдань, що мають бути виконані задля формування європейського енергетичного простору, а саме: запровадження нормативноправової бази з енергетики, навколишнього середовища, конкурентної політики та відновлюваних джерел енергії, з урахуванням як інституційної структури Енергетичного Співтовариства, так і конкретної ситуації кожної $з$ Договірних Сторін; установлення певної регуляторної системи, що уможливлює ефективне функціонування ринків мережевих енергопродуктів та охоплює створення єдиного механізму їх транскордонного передання та (або) транспортування, а також здійснення нагляду за дотриманням заходів з безпеки; створення ринку мережевих енергопродуктів без внутрішніх кордонів, у т. ч. координація взаємодопомоги у разі порушень у функціонуванні енергетичних мереж або зовнішніх пошкоджень, яка може охоплювати досягнення спільної енергетичної зовнішньоторговельної політики (створення єдиного енергетичного ринку).

3 огляду на зазначені умови формування європейського енергетичного простору систему відносин (зв'язків) у його межах складають: правовідносини у сфері енергетики, навколишнього середовища, конкурентної політики та відновлюваних джерел енергії як відносини, правове регулювання яких може бути імперативним і диспозитивним; правовідносини у сфері управління господарською діяльністю в енергетичному секторі (правова природа цих відносин обумовлена загальним принципом «заборонено все, що прямо не дозволено законом», який визначає відносини між суб'єктом

ISSN 1681-6277. Економіка та право. № 3 (48), 2017 
господарювання та суб'єктом владних, зокрема організаційно-господарських повноважень); відносини у сфері енергетики, навколишнього середовища, конкурентної політики та відновлюваних джерел енергії, які не врегульовані правовими нормами (стосовно цих відносин діє загальний принцип «дозволено все, що прямо не заборонено законом»).

3 наведеного визначення випливає, що європейський енергетичний простір структурно охоплює дві компоненти - правовий енергопростір, елементами якого є перші дві групи правовідносин, та так звану нерегульовану, «вільну» компоненту, яка складається з відносин, не врегульованих правом. Водночас обидві компоненти є взаємопов'язаними та взаємозалежними. Так, правове регулювання як динамічне явище може поширюватися на ті відносини, які до певного моменту регулювалися звичаєм або не мали регулювання взагалі, але 3 набуттям ними суттєвого значення для суспільного розвитку потребують урегулювання на законодавчому рівні (як це відбувалося 3 використанням газу (метану) вугільних родовищ, сонячною та вітровою енергією, яка вироблялася у приватних домогосподарствах).

Іншою формою правового впливу на «вільну» компоненту є стимулювання бажаного розвитку відносин на ринку та встановлення механізму захисту від небажаного розвитку відносин за принципом consuetudo volentes $d u$ cit; lex nolentes trahit (звичай веде за собою того, хто хоче; закон тягне за собою того, хто не хоче). Приміром такого підходу є відносини конкуренції. Як зазначає О.О. Бакалінська, добросовісна конкуренція - це якісна характеристика поведінки учасника конкурентних відносин, його внутрішнє сприйняття морально-етичних цінностей суспільного, зокрема економічного, розвитку. Ї̈і неможливо регулювати шляхом застосування заходів державного регулювання, можна лише забезпечити умови для мотивування учасників, які визнають необхідність розвитку економічної конкуренції та дотримання правил і принципів добросовісного конкурентного змагання. Правовими засобами такого мотивування можуть бути спрощення реєстраційних процедур створення нових суб'єктів господарювання, зменшення кількості перевірок тощо [27, с. 182-212]. Прояви недобросовісної конкуренції є підставою для застосування захисних механізмів.
Водночас «вільна» компонента як майданчик, на якому активно використовуються інноваційні продукти, також впливає на динаміку правового регулювання. Наприклад, використання споживачем геотермальної енергії шляхом встановлення теплових насосів для підігріву води винятково для власного споживання не є предметом регулювання з огляду на нечисленність відповідних випадків на сучасному етапі та відсутність помітного впливу на загальну ситуацію на ринку теплової енергії. Але якщо кількість абонентів багатоквартирного будинку, які обрали такий спосіб задоволення своїх потреб, та відповідно відмовились від послуг з централізованого гарячого водопостачання, зростатиме, умовно-постійні витрати постачальника на забезпечення решти абонентів збільшаться, що призведе до підвищення тарифів, додаткового навантаження на бюджет та ін. За таких умов виникає потреба у коригуванні правового регулювання у сфері будівництва, планування територій, житловокомунального господарства, енергетики тощо.

Висновки. У загальному вигляді енергетичний простір можна визначити як систему зв'язків між сторонами (на національному рівні - внутрішніми «гравцями» - суб'єктами організаційно-господарських повноважень, суб'єктами господарювання та споживачами) з приводу обігу мережевих енергопродуктів, яка у своїй структурі містить юридичний та інші (економічний, технічний тошо) елементи. Суспільні відносини, що входять до зазначеної системи, згруповані за функиіональним критерієм, утворюють торговельно-виробничу, інвестиційну, регулятивну складові енергопростору. За критерієм інтересу, на досягнення якого спрямовані дії різних за правовим статусом та суб'єктними ознаками учасників, зазначені відносини формують основні рівні функціонування енергопростору - індивідуальний, колективний, національний, наднаціональний. Водночас усі відносини, що входять до системи зв'язків у енергетичному просторі, поділяються на врегульовані, і не врегульовані правом. Отже структурно енергопростір охоплює дві взаємопов'язані та взаємозалежні компоненти: правовий енергопростір та так звану нерегульовану, «вільну» компоненту, яка складається з відносин, не врегульованих правом.

Передумовою створення ефективної правової моделі енергопростору є формування 
цілісного теоретичного уявлення про правову сутність взаємозв'язків, що складаються у ньому. Розв'язання теоретичних питань щодо економіко-правової сутності, структури та меж енергетичного простору сприятиме створенню підгрунтя для встановлення закономірностей його розвитку, а це у сукупності дасть змогу визначити методологію правового моделювання енергопростору.

\section{СПИСОК ЛІТЕРАТУРИ}

1. Джумагельдієва Г.Д. Правова сутність та структура енергопростору агломерації. Теорія і практика управління розвитком агломерацій: монографія. За ред. С.В. Богачова, М.В. Мельникової, В.А. Устименко. Харків, 2017. 295 с.

2. Про заходи щодо запобігання енергетичній кризі в Україні: Постанова Верховної Ради України від 06.10.2005 № 2966-IV. Відомості Верховної Ради України. 2005. № 49. Ст. 524.

3. Оржель О. Чинники формування Європейського адміністративного простору. Вісник Національної академії державного управління при Президентові України. 2011. № 2. C. $65-73$.

4. Про затвердження Умов та Правил здійснення підприємницької діяльності з передачі електричної енергії магістральними та міждержавними електричними мережами: Постанова Нацкомелектроенергетики України від 11.10.1996 № 152. URL: http:// zakon2.rada.gov.ua/laws/show/z0637-96 (дата звернення 10.08.2017).

5. Познер Ричард А. Економічний аналіз прав: монографія. Пер. з англ. С. Савченка. К., 1998. 862 с.

6. Публічна власність: проблеми теорії та практики: монографія. За ред. В.А. Устименка. Чернігів, 2014. 308 с.

7. Носік В.В. Проблеми здійснення права власності на землю Українського народу: автореф. дис. ... д-ра юрид. наук: 12.00.06. Київ, 2007. 34 с.

8. Каминская Е.И. Регулирование отношений, связанных с недвижимостью. «Черные дыры» в российском законодательстве. 2002. № 3. С. 253-260.

9. Джумагельдієва Г.Д. Правове регулювання господарського використання природних ресурсів: монографія. Київ, 2015. 170 с.

10. Hardy C. Swiss referendum on renewable energy. URL: http://www.euronews.com/2017/05/21/swiss-referendumon-renewable-energy (last accessed 09.08.2017).

11. Human Development Report-1990. New York, 1990. 141 p.

12. Human Development Report 2010. 20th Anniversary Edition. The Real Wealth of Nations: Pathways to Human Development. URL: http://hdr.undp.org (last accessed 16.08.2017).

13. Мамутов В.К. Про публічну власність у змішаній економіці. Економіка та право. 2013. № 1. С. 5-18.

14. Мамутов В.К. Посилення публічних засад у правовому регулюванні господарської діяльності. Право України. 2009. № 9. С. 85-94.

15. Розовский Б.Г. Возврат от публичной собственности к всенародной как основа прогресса, или о пользе утопий. Экономико-правовые исследования в ХХІ веке: правовые проблемы эффективного использования объектов публичной собственности: материалы Седьмой междунар. науч.-практ. интернет-конф. Донецк, 2011. C. $8-41$.

16. Макогон Ю.В., Ляшенко В.И. Национализация и приватизация предприятий (опыт Франции для Украины): монография. Донецк, 2009. 491 с.

17. Львов Д.С. Концепция управления национальным имуществом: науч. доклад. М., 2002.35 с.

18. Haddock David D. First Possession Versus Optimal Timing: Limiting the Dissipation of Economic Value. Washington University Law Quarterly. 1986. 64. № 3. P. 775-792.

19. Allen Douglas W. Homesteading and Property Rights, or How the West Was Really Won. The Journal of Law \& Economics. 1991. 34. № 1. P. 1-23.

20. Про затвердження Порядку надання у 2008 році спеціальних дозволів на користування надрами: Постанова Кабінету Міністрів України від 27.02.2008 № 273. Офіційний вісник України. 2008. № 25. Ст. 792.

21. Mauro F. The Brave New World of Sovereign Wealth Funds. University of Pennsylvania Research. 2010. URL: http://knowledge.wharton.upenn.edu/papers (last accessed 22.07.2017).

22. Шмарловская Г. Международные инвестиции суверенных фондов национального благосостояния. Банкаўскі веснік. 2010. Вересень. С. 35-41.

23. Підгурська О. І. Сутність та етапи розвитку фондів суверенного добробуту. Ефективна економіка. 2012. № 10. URL: http://www.economy.nayka.com.ua/?op= $1 \& z$ (дата звернення 20.07.2017).

24. Global Financial Stability Report: International Monetary Fund. 2012. April. URL: http://www.imf.org/external/ pubs/ft/gfsr/2012/01/pdf/c3.pdf (last accessed 22.07.2017).

25. Диба М.І., Краснова I.В. Суверенні фонди на ринку капіталів. Фінанси України. 2015. № 8. С. 56-73.

26. Бакалінська О.О. Правове регулювання добросовісної конкуренції в Україні: монографія. Київ, 2014. 373 с.

\section{REFERENCES}

1. Dzhumaheldiieva H.D. Pravova sutnist ta struktura enerhoprostoru ahlomeratsii. Teoriia i praktyka upravlinnia rozvytkom ahlomeratsii: monohrafiia. Pid red. S.V. Bohachova, M.V. Melnykovoi, V.A. Ustymenko. Kharkiv, 2017 [in Ukrainian].

2. Pro zakhody shchodo zapobihannia enerhetychnii kryzi v Ukraini: Postanova Verkhovnoi Rady Ukrainy vid 06.10.2005 No. 2966-IV. Vidomosti Verkhovnoi Rady Ukrainy. 2005. No. 49. St. 524 [in Ukrainian].

3. Orzhel O. Chynnyky formuvannia Yevropeiskoho administratyvnoho prostoru. Visnyk Natsionalnoi akademii derzhavnoho upravlinnia pry Prezydentovi Ukrainy. 2011. No. 2: 65-73 [in Ukrainian].

4. Pro zatverdzhennia Umov ta Pravyl zdiisnennia pidpryiemnytskoi diialnosti z peredachi elektrychnoi enerhii mahistralnymy ta mizhderzhavnymy elektrychnymy merezhamy: Postanova Natskomelektroenerhetyky Ukrainy vid 11.10.1996 No. 152. URL: http://zakon2.rada.gov. ua/laws/show/z0637-96 [in Ukrainian].

5. Pozner Rychard A. Ekonomichnyi analiz prav: monohrafiia. Per. z anhl. S. Savchenka. K., 1998 [in Ukrainian].

ISSN 1681-6277. Економіка та право. № 3 (48), 2017 
6. Publichna vlasnist: problemy teorii ta praktyky: monohrafiia. Za red. V.A. Ustymenko. Chernihiv, 2014 [in Ukrainian].

7. Nosik V.V. Problemy zdiisnennia prava vlasnosti na zemliu Ukrainskoho narodu: avtoref. dys. ... d-ra yuryd. nauk: 12.00.06. K., 2007 [in Ukrainian].

8. Kaminskaya E.I. Regulirovanie otnosheniy, svyazannyih s nedvizhimostyu. "Chernyie dyiryi» $v$ rossiyskom zakonodatelstve. 2002. No. 3: 253-260 [in Russian].

9. Dzhumaheldiieva H.D. Pravove rehuliuvannia hospodarskoho vykorystannia pryrodnykh resursiv: monohrafiia. K., 2015 [in Ukrainian].

10. Hardy C. Swiss referendum on renewable energy. URL: http://www.euronews.com/2017/05/21/swiss-referendumon-renewable-energy

11. Human Development Report-1990. New York, 1990.

12. Human Development Report 2010. 20 ${ }^{\text {th }}$ Anniversary Edition. The Real Wealth of Nations: Pathways to Human Development. URL: http://hdr.undp.org

13. Mamutov V.K. Pro publichnu vlasnist u zmishanii ekonomitsi. Ekonomika ta pravo. 2013. No. 1: 5-18 [in Ukrainian].

14. Mamutov V.K. Posylennia publichnykh zasad u pravovomu rehuliuvanni hospodarskoi diialnosti. Pravo Ukrainy. 2009. No. 9: 85-94 [in Ukrainian].

15. Rozovskiy B.G. Vozvrat ot publichnoy sobstvennosti k vsenarodnoy kak osnova progressa, ili o polze utopiy. Ekonomiko-pravovyie issledovaniya v XXI veke: pravovyie problemyi effektivnogo ispolzovaniya ob'ektov publichnoy sobstvennosti: materialyi Sedmoy mezhdunar. nauch.prakt. internet-konf. Donetsk, 2011 [in Russian].

16. Makogon Yu.V., Lyashenko V.I. Natsionalizatsiya i privatizatsiya predpriyatiy (opyit Frantsii dlya Ukrainyi): monografiya. Donetsk, 2009 [in Russian].

17. Lvov D.S. Kontseptsiya upravleniya natsionalnyim imuschestvom: nauch. doklad. M., 2002 [in Russian].

18. Haddock David D. First Possession Versus Optimal Timing: Limiting the Dissipation of Economic Value. Washington University Law Quarterly. 1986. Vol. 64. No. 3: 775-792.

19. Allen Douglas W. Homesteading and Property Rights, or How the West Was Really Won. The Journal of Law \& Economics. 1991. Vol. 34. No 1: 1-23.

20. Pro zatverdzhennia Poriadku nadannia u 2008 rotsi spetsialnykh dozvoliv na korystuvannia nadramy: Postanova Kabinetu Ministriv Ukrainy vid 27.02.2008 No. 273. Ofitsiinyi visnyk Ukrainy. 2008. No. 25 [in Ukrainian].

21. Mauro F. The Brave New World of Sovereign Wealth Funds. University of Pennsylvania Research. 2010. URL: http:// knowledge.wharton.upenn.edu/papers

22. Shmarlovskaya G. Mezhdunarodnyie investitsii suverennyih fondov natsionalnogo blagosostoyaniya. Bankay̆ski vesnik. 2010. Veresen: 35-41 [in Russian].
23. Pidhurska O. I. Sutnist ta etapy rozvytku fondiv suverennoho dobrobutu. Efektyvna ekonomika. 2012. No. 10. URL: http://www.economy.nayka.com.ua/?op=1\&z [in Ukrainian].

24. Global Financial Stability Report: International Monetary Fund. 2012. April. URL: http://www.imf.org/external/ pubs/ft/gfsr/2012/01/pdf/c3.pdf

25. Dyba M.I., Krasnova I.V. Suverenni fondy na rynku kapitaliv. Finansy Ukrainy. 2015. No. 8: 56-73 [in Ukrainian].

26. Bakalinska O.O. Pravove rehuliuvannia dobrosovisnoi konkurentsii v Ukraini: monohrafiia. Kyiv, 2014 [in Ukrainian].

Надійшла 26.08.2017

\section{Г.Д. Джумагельдиева, Н.В. Еремеева}

Институт экономико-правовых исследований НАН Украины, г. Киев

\section{ЭКОНОМИКО-ПРАВОВАЯ СУЩНОСТЬ И СТРУКТУРА ЭНЕРГЕТИЧЕСКОГО ПРОСТРАНСТВА}

На основе анализа нормативно-правовых актов ЕС, в частности. Договора об учреждении Энергетического Сообщества, исследована экономико-правовая сущность, определена структура европейского энергетического пространства, природа взаимосвязей между его ключевыми элементами.

Ключевые слова: мировое энергетическое пространство, европейское энергетическое пространство, составляющие энергетического пространства, правовое энергетическое пространство, свободная компонента энергетического пространства.

\section{H.D. Dzhumaheldiyeva, N.V. Eremeeva}

Institute of Economic and Legal Researches of the NAS of Ukraine, Kyiv

\section{THE ECONOMIC AND LEGAL ESSENCE AND STRUCTURE OF THE ENERGY SPACE}

Based on the analysis of legal acts of the EU, in particular, the Treaty establishing the Energy Community, the economic and legal essence was investigated, the structure of the energy space, the nature of the interconnections between its key elements were determined.

Keywords: world energy space, European energy space, components of energy space, legal energy space, free component of energy space. 